\title{
Self-esteem, forgiveness, perception of family harmony, and subjective well-being in adolescents
}

Utami, Muhana Sofiati $\bowtie$

Universitas Gadjah Mada, Indonesia (muhana@ugm.ac.id)

Praptomojati, Ardian

Universitas Gadjah Mada, Indonesia (ardian.praptomojati@gmail.com)

Wulan, Dita Lestari Ari

Universitas Gadjah Mada, Indonesia (ditalestariariwulan@gmail.com)

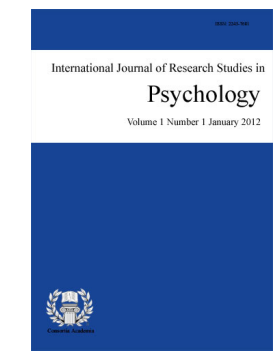

ISSN: 2243-7681 Online ISSN: 2243-769X

OPEN ACCESS

Fauziah, Yunita

Universitas Gadjah Mada, Indonesia (yunitafauziah@gmail.com)

\section{Abstract}

Subjective well-being is one indicator of individual's and society's quality of life. Adolescent subjective well-being should therefore be studied to understand the factors that may promote life satisfaction and positive affect of adolescents. These factors mitigate the negative effects of stressful life events against the development of psychological and behavioral problems. This study aims to determine the role of self-esteem, forgiveness, and perception of family harmony in subjective well-being of adolescents. Subjects of this study were 226 adolescents (aged 12-21 years old). The result of multiple regression analysis indicated that self-esteem, forgiveness, and perception of family harmony simultaneously served as predictors of subjective well-being in adolescents $(\mathrm{F}=48.271 ; p<.01)$. However, from beta coefficients of each predictor, it was evident that only self-esteem served as a predictor of adolescents' subjective well-being $(p<.01)$, whereas forgiveness and perception of family harmony did not serve as predictors of subjective well-being in adolescents $(p>.05)$. The results also showed that the coefficient of multiple determination for subjective well-being was 0.387 (seen from Adjusted R Square), meaning that $38.7 \%$ variance of subjective well-being in adolescents of this study was influenced by self-esteem, forgiveness, and the perception of family harmony, while $61.3 \%$ was influenced by other variables.

Keywords: forgiveness; perception of family harmony; self-esteem; subjective well-being; adolescent 


\section{Self-esteem, forgiveness, perception of family harmony, and subjective well-being in adolescents}

\section{Introduction}

Positive psychology is a contemporary approach in psychology pioneered by Martin E. P. Seligman in 1998 (Compton \& Hoffman, 2013; Compton, 2005; Snyder \& Lopez, 2007). The emergence of the positive psychology movement has prompted scientists to examine other angles in the domain of psychology that had previously been neglected. While during the past decade scientists put more emphasis on negative aspects and various dysfunctions of human behavior, the recent emergence of positive psychology that focus more on studying positive aspects of human behavior is a breath of fresh air in the development of psychology as a science (Compton, 2005; Miller \& Harvey, 2001; Simonton \& Baumeister, 2005).

One realm of positive psychology that interests many scientists is research on well-being (Compton, 2005; Larsen \& Eid, 2008; Pavot, 2008; Snyder \& Lopez, 2007). Subjective well-being becomes an important component of positive well-being and the good life (Diener, Sapyta, \& Suh 1998). How individuals perceive and see themselves, as well as how they assess their lives, becomes the basis of subjective well-being. Diener, Suh, and Oishi (1997) explained subjective well-being as an evaluation of a person's entire life, including variables such as life satisfaction, minimum amount of negative affect - such as depression and anxiety - as well as positive feelings that emerge in a person (Diener, 1984; Diener et al., 1997; Diener et al., 1998; Diener, 2006). Ordinary people call it happiness, tranquility, fully functioning, and life satisfaction (Diener, Oishi, \& Lucas, 2003).

During the last few decades, studies focusing on subjective well-being have developed rapidly (Compton, 2005; Snyder \& Lopez, 2007). Almost every relevant study suggested that high levels of subjective well-being are able to give considerable positive influence on individuals' lives (Diener \& Ryan, 2009; Eid \& Diener, 2004; Larsen \& Eid, 2008). Individuals who have high level of subjective well-being will have better social relationships in comparison to individuals with low level of subjective well-being (Diener \& Seligman, 2002). Positive feelings related to subjective well-being is also able to predict age longevity and optimal health (Diener \& Chan, 2011). Subjective well-being is also associated with the level of success in life, for example in harmony relationships and marital satisfaction, success in career and high job satisfaction, the ability to cope with stress, as well as a more optimal health condition (Pavot \& Diener, 2004).

Achieving subjective well-being becomes very important for adolescents as it is a factor that can protect them from negative effects of stressful situations, such as juvenile delinquency, smoking and alcohol drinking, drug abuse, depression, anxiety, loneliness, and psychological problems alike (Basson, 2008). Studies (Gilman \& Huebner, 2006; Proctor, Linley, \& Maltby, 2010) showed that happy adolescents are satisfied with their life and feel more positive affect than negative affect, performing various positive functions in various domains of life, such as intrapersonal, interpersonal, and school life. Raboteg-Šarić, Brajša-Žganec, and Šakić (2008) also explained that adolescents who have high life satisfaction will have high physical health and mental health.

Adolescence is often described as a period of storm and stress, a transition period both physically and psychologically from childhood towards adulthood (Hurlock, 2002). In times of transition, adolescents face various developmental tasks that lead to their role as an adult, hence this important if this period is passed positively and happily (Metzler et al., 2007). Developmental tasks in adolescence that are accompanied by the increase of expectation both from himself and from others make adolescents prone to psychological problems, either in the form of disturbance -- mentally, emotionally or behaviorally (Havlicek, Garcia, \& Smith, 2013; Hawkins et al., 2000; Metzler et al., 2007; Southerland, Casanueva, \& Ringeisen, 2009). Stress, sadness, anxiety, loneliness, and self-doubt in adolescents lead them in risks of doing delinquency (Rojas \& Coker, 2015; 
Self-esteem, forgiveness, perception of family harmony, and subjective well-being in adolescents

Fuhrmann, 1990). Hurlock (2002) mentioned that, basically, adolescents tend to have more problems towards themselves than to others. When they are not able to adjust to their new role in life, they will experience confusion, uncertainty, and anxiety (Santrock, 2003). This may indicate low level of adolescent subjective well-being.

Subjective well-being is influenced by various factors, such as personality (Diener, Suh, Lucas, \& Smith, 1999; DeNeve, 1999), demography condition -- age, gender, race, occupation, education, marital status - (Diener, 1984), religiosity (Abdel-Khalek, 2011), cognitive factor (Diener et al., 1997), social relations (Diener \& Ryan, 2009), activity (Diener et al., 1997), culture (Diener et al., 1997), family (Rask, Åstedt-Kurki, Paavilainen, \& Laippala, 2003), coping and adaptation (Diener et al., 1999), and biological factor (Larsen \& Eid, 2008). Due to its importance, research on subjective well-being in adolescent is interesting for further investigation. One of the factors that are considered important in the achievement of subjective well-being is self-esteem (Ayyash \& Alamuddin 2007; Benet-Martínez \& Karakitapoğlu-Aygun, 2003; DeNeve, 1999; Lucas, 2008; Schimmack \& Diener 2003; Purnama, 2006). Santrock (2003) stated that adolescents are in transition and crisis situation in discovering their identity, hence feeling worthy and valuable for them is very essential. Adolescents with low self-esteem will lack confidence and incapable of combining hard work, perseverance, and tenacity in achieving success. They are less confident in their ability to overcome obstacles. This can steer adolescents to negative behaviors such as aggression, antisocial and deviant behavior, drug abuse, depression, and high anxiety (Boden, Fergusson \& Horwood, 2008; Donnellan, Trzesniewski, Robins, Moffitt, \& Caspi, 2005; Retnowati \& Munawarah, 2009). On the other hand, adolescents who have high self-esteem will be more motivated to achieve success in life (Subowo \& Martiarini 2009) leading them to have high satisfaction in life (Baumeister, Campbell, Krueger, \& Vohs, 2003; Boden et al., 2008; Pudjijogyanti, 1995; Raboteg-Šarić et al., 2008) and more positive emotions (Coopersmith, 1967). This condition indicates high level of subjective well-being, and it is very important for an adolescent.

Self-esteem is defined as an individual assessment of himself that reflects his attitude of acceptance or rejection and shows how far the individual believes himself as a capable, important, successful and valuable person (Coopersmith, 1967). Self-esteem consists of the evaluation process towards himself within a range of positive and negative dimensions such as abilities, skills, social relationships, and future results (Baron \& Byrne, 2003; Heatherton \& Wyland, 2003; Myers, 2008). Coopersmith (1967) explained that self-esteem is an essential requirement in the formation of effective behavior.

Other studies found that in addition to self-esteem, forgiveness variable is evidently also important and is associated with the level of subjective well-being (Chan, 2013; Peterson, 2015; Plauča \& Bite, 2011). Adolescents are faced with various demands and expectations from either the environment or themselves hence when they are unable to comply, psychological problems will occur (Havlicek et al., 2013; Metzler et al., 2007; Hawkins et al., 2000). Inability to forgive and forget mistakes or disappointments that cause domination of negative affect over positive can lead to low levels of subjective well-being (McCullough, Bellah, Kilpatrick, \& Johnson, 2001; McCullough, 2000; McCullough et al., 1998). When a person does forgiveness, he will develop positive emotions, positive thoughts, and positive attitude toward the offender or source of his pain (Enright, 2001; Thompson et al., 2005) so that level of life satisfaction and positive affect increased, and the level of negative affect decreases (Chan, 2013; Peterson, 2015; Worthington \& Wade, 1999).

Forgiveness is defined as the process to accept mistakes done by the wrongdoer or forgiven object by attempting recovery of emotional wounds and the desire to establish a new relationship in the future (Williamson \& Gonzales, 2007). Thompson and Snyder (2003) explained that there are two aspects that play role in forgiveness: interpersonal and intrapersonal aspects. Forgiveness also can be divided into three domains, namely the forgiveness of self, forgiveness of others, and forgiveness of situation (Thompson et al., 2005). Flanagan, Hoek, Ranters, and Reich (2012) stated that forgiveness is an adaptive and effective coping strategy for adolescents. By forgiving, adolescents are able to maintain positive internal condition, as well as positive interpersonal relationships and interactions with peers. Some studies also showed that forgiveness is positively 
correlated with psychological well-being (Krause \& Ellison, 2003; Wohl, DeShea, \& Wahkinney, 2008; Bono, McCullough, \& Root, 2007) and emotional well-being (Malone et al., 2011 ).

Subjective well-being also cannot be separated from the family context (Andayani \& Koentjoro, 2004; Chuang, 2005; Papalia, Olds, \& Feldman, 2008; Primasari \& Yuniarti, 2012). Adolescents who grew up in a harmonious family, where in it exists love, tolerance, a sense of security and warmth, will be able to adapt healthily, more happily, and be better prepared for the future (Chuang, 2005; Deepshikha \& Bhanot 2009; Joronen, 2005; Lee, 2003). Conversely, adolescents who are raised in the inharmonious family will be at risk for experiencing psychological problems and juvenile delinquency (Aufseeser, Jekielek, \& Brown, 2006; Marina, 2000; Hawkins et al., 2000). According to ecological theory, Bronfenbenner and Morris (1998) stated that one of the environmental factors that have a great impact in the construction of subjective well-being in adolescents is social interaction in the family. Closeness and openness in the family can endorse adolescent to have positive perception of his family, and associated with the level of adolescent subjective well-being.

Stinnett and Defrain (Olson \& Defrain, 2014) defined the perception of family harmony as meaning and attribution, both positively and negatively, a person has - in this case, adolescents - towards family life that compromises their father, mother, and siblings. This variable consists of six main aspects: commitment to family, enjoying time together, the ability to manage stress and crisis effectively, spiritual well-being, positive communication, appreciation and affection. When all aspects can be achieved, the adolescent will be able to adapt positively in facing stressors and will achieve high level of subjective well-being.

Based on the above elaboration, subjective well-being problem in adolescents is an important topic that needs to be addressed. This study aimed to determine the role of self-esteem, forgiveness, and the perception of family harmony on subjective well-being among adolescents. Results are expected to be used as the basis and foundation of treatment and prevention programs that are expected to increase subjective well-being among adolescents.

The hypothesis of this study:

$>$ Self-esteem, forgiveness, and the perception of family harmony are predictors of subjective well-being in adolescents.

$>$ Self-esteem is a predictor of subjective well-being in adolescents.

$>$ Forgiveness is a predictor of subjective well-being in adolescents.

$>$ Perception of family harmony is a predictor of subjective well-being in adolescents.

\section{Method}

\subsection{Research Subject}

This research used convenient sampling strategy to collect sample. The number of subjects was 226 adolescents consisting of early adolescents $(\mathrm{N}=76 ; 33.63 \%)$, mid-adolescents $(\mathrm{N}=85 ; 37.61 \%)$, and late adolescents $(\mathrm{N}=65 ; 28.76 \%)$. The division of adolescence was used based on Mönks, Knoers, and Haditono's concept (2004), with an age range of 12 to 21 years (12-15 years as early adolescence; 15-18 years as a mid-adolescence; and 18- 21 years as late adolescence). By gender, the number of subjects was dominantly women $(\mathrm{N}=148 ; 65.49 \%)$ in comparison to the number of male subjects $(\mathrm{N}=78 ; 34.51 \%)$.

\subsection{Identification of Research Variables}

This study consisted of one dependent variable, namely subjective well-being, and three independent variables, namely self-esteem, forgiveness, and the perception of family harmony. 


\subsection{Research Instruments}

The method used in this study was survey. The tools used to collect data consisted of: Scale of Subjective Well-being which was a modified version of Utami's (2010), Self-Esteem Scale which was a modification of the Self-Esteem Inventory (SEI) -- a shorter form of Coopersmith's (1967), and Forgiveness scale which was a modified version of Wulandari's Forgiveness Scale (2009), and Perception of Family Harmony Scale which was a modification of Astuti's Perception of Family Harmony Scale (1999). After receiving professional judgments to keep the internal validity, all of the scales were field-tested before being used for the main data collection. The data from the field testing were used to eliminate some items which were not qualified to be used and potential to lower the reliability and validity of the scales.

Subjective Well-Being Scale - Subjective Well-Being Scale used to measure Subjective Well-Being among adolescent in this study was a modified version of Utami's (2010). The Scale used the Diener concept of Subjective Well-Being that stated Subjective Well-Being consists of three components: life satisfaction, positive affects, and negative affects. Subjective Well-Being Scale which was a modification of the Utami Subjective Well-Being Scale (2010) originally comprised of 27 items of Positive Affect Subscale, 29 items of Negative Affect Subscale, and 26 items of Life Satisfaction Subscale with the value of coefficient reliability Alpha Cronbach 0.939. After Subjective Well-Being Scale was field-tested to adolescents $(\mathrm{N}=93)$, there were 25 items of Positive Affect Subscale, 27 items of Negative Affect Subscale, and 24 items of Life Satisfaction Subscale with the value of coefficient reliability Alpha Cronbach 0.879. At the time of the research process, researchers also checked the reliability of the Subjective Well-Being Scale and the value of coefficient reliability Alpha Cronbach was 0.893.

Self-Esteem Inventory - Self-Esteem Inventory used to measure Self-Esteem among adolescent in this study was a modified version of short-form Self Esteem Inventory (SEI) from Coopersmith (1967) developed in Indonesia by Eryunanti (2000) with 30 items and the value of coefficient reliability of Alpha Cronbach 0.896. Researchers then made modifications and increased the number of items into 48 items. After Self-Esteem Inventory was field-tested to adolescents $(\mathrm{N}=101)$, there were 39 items of Self-Esteem Scale with the value of coefficient reliability Alpha Cronbach 0.914. At the time of the research process, researchers also checked the reliability of the Self-Esteem Scale and the value of coefficient reliability Alpha Cronbach was 0.881 .

Forgiveness Scale - Forgiveness Scale used to measure Forgiveness among adolescent in this study was a modified version of Wulandari Forgiveness Scale (2009) using the Williamson and Gonzales (2007) concept of forgiveness which originally consisted of 27 items with the value of coefficient reliability Alpha Cronbach 0.924 and modified into 60 items. After Forgiveness Scale was field-tested to adolescents $(\mathrm{N}=98)$, there were 45 items of Forgiveness Scale with the value of coefficient reliability Alpha Cronbach 0.953. At the time of the research process, researchers also checked the reliability of Forgiveness Scale and the value of coefficient reliability Alpha Cronbach was 0.929 .

Perception of Family Harmony Scale - Perception of Family Harmony Scale used to measure Perception of Family Harmony Scale among adolescent in this study was a modified version of Astuti's (1999) based on the Stinnettt \& DeFrain theory (Olson \& DeFrain, 2014). This scale originally comprised of 58 items with the value of coefficient reliability Alpha Cronbach 0.958 and then modified into 56 items. After Forgiveness Scale was field-tested to adolescents $(\mathrm{N}=97)$, there were 45 items of Perception of Family Harmony Scale with the value of coefficient reliability Alpha Cronbach 0.936. At the time of the research process, researchers also checked the reliability of Perception of Family Harmony Scale and the value of coefficient reliability Alpha Cronbach was 0.890.

\subsection{Analysis}

Analysis of this research data using multiple regression analysis to determine the role of Self-Esteem, Forgiveness, and Perception of Family Harmony of Subjective Well-Being. The analysis was conducted using IBM Statistical Package for Social Sciences (SPSS) Statistics 24 program. 


\section{Results}

The hypotheses were tested using multiple regression analysis. Before performing the multiple regression analysis, multicollinearity test was done to determine whether independent variables (predictors) are related to one another in a near-perfect manner. Based on the multicollinearity assumption (see Table 1), it can be seen that the value of Variance Inflation Factor (VIF) equaled to 1.28 esteem; VIF for forgiveness was 1.23; and perceptions of family harmony' VIF value was 1.05. Assuming the occurrence of multicollinearity (the correlation among predictors) is that if VIF is less than 1 or exceeds 10 , or if the tolerance value is less than 0.1 (Triton, 2006). Under this provision, it can be concluded that the assumption of multicollinearity did not occur others predictor (independent variable). This showed that among the predictors (independent variables), which consisted of self-esteem, forgiveness, and the perception of family harmony, there was no multicollinearity relationship.

\section{Table 1}

Coefficient of Tolerance Value and VIF

\begin{tabular}{|c|c|c|c|c|c|}
\hline & \multirow{2}{*}{$t$} & \multirow{2}{*}{ Significance } & \multicolumn{2}{|c|}{ Collinearity Statistic Collinearity } & \multirow{2}{*}{ Explanation } \\
\hline & & & Tolerance & VIF & \\
\hline Constant & -9.49 & .000 & & & \\
\hline Self-Esteem & 10.16 & .000 & .78 & 1.28 & $\begin{array}{l}\text { Multicollinearity } \\
\text { Did Not Occur }\end{array}$ \\
\hline Forgiveness & .87 & .385 & .81 & 1.23 & $\begin{array}{l}\text { Multicollinearity } \\
\text { Did Not Occur }\end{array}$ \\
\hline $\begin{array}{l}\text { Perception of Family } \\
\text { Harmony }\end{array}$ & .49 & .626 & .95 & 1.05 & $\begin{array}{l}\text { Multicollinearity } \\
\text { Did Not Occur }\end{array}$ \\
\hline
\end{tabular}

In the Summary of Anova in Table 2, it can be seen that the value of F regression $=48.27(p<0.01)$. This means that the regression model could be used to predict subjective well-being, or self-esteem, forgiveness, and the perception of family harmony simultaneously served as predictors of subjective well-being of adolescents. The analysis results of these data supported the proposed hypothesis. The multiple coefficients of determination for the subjective well-being constant was 0.387 (seen from Adjusted R Square), which meant that $38.7 \%$ of subjective well-being's variance owned by adolescents in this study were influenced by self-esteem, forgiveness, and the perception of family harmony, while $61.3 \%$ was influenced by other variables.

\section{Table 2}

Anova Summary

\begin{tabular}{lccccc}
\hline & Sum of Squares & $d f$ & Mean Square & $F$ & Sig. \\
\hline Regression & 444.23 & 3 & 148.08 & 48.27 & .000 \\
Residual & 681.01 & 222 & 3.07 & & \\
Total & 1125.23 & 225 & & & \\
\hline
\end{tabular}

The role of predictors independently (self-esteem, forgiveness, and the perception of family harmony) towards the criteria (subjective well-being) of adolescents can be seen through the beta coefficient of each predictor shown in Table 3.

Table 3

Coefficient Predictor of Subjective Well-Being

\begin{tabular}{|c|c|c|c|c|c|c|}
\hline & \multirow[t]{2}{*}{ Model } & \multicolumn{2}{|c|}{$\begin{array}{l}\text { Unstandardized } \\
\text { Coefficients }\end{array}$} & \multirow{2}{*}{$\begin{array}{c}\text { Standardized } \\
\text { Coefficients }\end{array}$} & \multirow[t]{2}{*}{$T$} & \multirow[t]{2}{*}{ Sig. } \\
\hline & & Beta & Std. Error & & & \\
\hline \multirow[t]{4}{*}{1} & (Constant) & -14.75 & 1.55 & & -9.49 & .000 \\
\hline & Self-Esteem & .10 & .01 & .60 & 10.16 & .000 \\
\hline & Forgiveness & .01 & .01 & .05 & .87 & .385 \\
\hline & Perception of Family Harmony & .00 & .01 & .03 & .49 & .626 \\
\hline
\end{tabular}


Self-esteem, forgiveness, perception of family harmony, and subjective well-being in adolescents

Further understanding the data analysis of this study (see Table 3) in the independent role of predictors towards criteria, self-esteem alone played a role as a predictor of subjective well-being, with $p=0.000(p<0.01)$. Meanwhile, forgiveness did not play a role as a predictor of subjective well-being in adolescents, with $p=0.385(p>0.05)$. Similarly, the perception of the family harmony also did not play a role as a predictor of subjective well-being in adolescents, with $p=0.626$ ( $p>0.05)$. These results indicated that the hypothesis which stated that self-esteem serves as predictors of subjective stood correctly (accepted). However, the hypothesis that stated forgiveness as a predictor of subjective well-being of adolescents, and the perception of family harmony as a predictor of subjective well-being of adolescents were rejected.

Based on the calculation results of self-esteem, forgiveness, and the perception of family harmony's statistical coefficients as predictors of subjective well-being as criteria (see Table 3), then the regression equation is:

$$
\mathrm{Y}^{\prime}=-14.75+0.10 \mathrm{X}_{1}+0.01 \mathrm{X}_{2}+0.00 \mathrm{X}_{3} \quad \text { or }
$$

Subjective Well-Being $=-14.75+0.10$ Self-Esteem +0.01 Forgiveness +0.00 Perception of Family Harmony

Using this formula, if one of the variable's value is known, the value of the other variable can be predicted or forecasted.

\section{Discussion}

Statistical test results proved that together, self-esteem, forgiveness, and the perception of family harmony were predictors of subjective well-being in adolescents. But when seen individually, the effect towards the criteria, only the self-esteem predictor played a role in subjective well-being, whereas the two other predictors (forgiveness and perception of family harmony) did not have roles in the subjective well-being of adolescents. This is a new finding because based on previos studies, both forgiveness and perception of family harmony play a role in subjective well-being (Chan, 2013; Peterson, 2015; Plauča \& Bite, 2011; Olson \& DeFrain, 2014).

Based on the results, it can be seen that self-esteem was the most influential variable on subjective well-being in adolescents, either when analyzed together or separately. This is in line with previous studies showing that self-esteem is correlated with subjective well-being (Ayyash \& Alamuddin 2007; Benet-Martínez \& Karakitapoğlu-Aygun, 2003; DeNeve, 1999; Lucas, 2008; Raboteg-Šarić et al., 2008; Schimmack \& Diener, 2003; Purnama, 2006). People with high level of self-esteem will have high level of subjective well-being as well. Leary and colleagues (1995) stated that individuals with high self-esteem will feel satisfaction, confidence, and pride in themselves, while individuals with low self-esteem tend to feel stupid, shy, not adequate and awkward. In responding to failure, individuals with high self-esteem tend to exhibit non-negative emotional reactions such as those with low self-esteem (Dogson \& Wood, 1998). High self-esteem also serves as a protective factor for the emergence of psychological disturbances that are harmful to the individual. High self-esteem can increase the individual's well-being while low self-esteem will lead to involvement in the deviant activity, psychological pressure, and victimization (Steinberg, 2002).

Self-esteem becomes an internal component that is capable of steering individuals to the self-attainment in life success (Baumeister et al., 2003; Santoso, 2011). Adolescents who have high self-esteem will be more motivated to achieve success in life. They are more motivated to achieve and do not hesitate to compete with other individuals because they appraise themselves positives and will be accepted by the people surrounding them. The experience of success accounted by adolescents will make them feel satisfaction in life (Baumeister et al., 2003; Boden et al., 2008; Pudjijogyanti, 1995; Raboteg-Šarić et al., 2008). In addition to experiencing life satisfaction, individuals with high self-esteem will be more active, expressive, and not feel anxious in actions they take (Coopersmith, 1967). Self-esteem will also make a person feel more positive emotions like happiness in comparison to negative emotions such as anxiety or sad (Baumeister et al., 2003). This is a condition of adolescents with a high subjective well-being, 
which is dominated by life satisfaction and positive affect and low negative affect (Diener et al., 1997; Diener et al., 1998; Diener, 2006).

The results also confirmed the theory advanced by Hurlock (2002) which stated that adolescents' happiness is determined by adolescents' attitude towards themselves. When an adolescent is able to accept himself, to make a realistic assessment of his strengths and weaknesses and has no significant difference between their actual personality and ideal ego, then they will feel happy. On the other hand, adolescents feel unhappy because they set unrealistic ideal standards that are difficult to achieve. Failure to achieve ideal self-standard lead to self-rejection while considering themselves worthless. They are not able to achieve optimal level of subjective well-being and will also have a relatively low quality of life (Eid \& Diener, 2004). Furthermore, they have a high risk of psychological problems (Havlicek et al., 2013; Hawkins et al., 2000; Metzler et al., 2007; Southerland et al., 2009).

Erikson explained that one of the most important developmental tasks of is to build concepts about himself (Santrock, 2003). At this time, adolescents have a dominant attitude of self-evaluation and social comparison. Study (Erol \& Orth, 2011) showed that self-esteem will develop optimally in adolescence stage. At this time, adolescent self-esteem will continue to change and this change depends on the condition of adolescents, whether to increase or even decrease. Hurlock (2002) mentioned that adolescents tend to have more problems with themselves than problems with others. Therefore, it is important for adolescents to have optimal self-esteem development as it is an important aspect for Subjective Well-Being of adolescents. Achieving subjective well-being will protect adolescents from the negative effects of stressful situations, such as youth violence, smoking and drinking, drug abuse, depression, anxiety, loneliness, and other psychological problems (Basson, 2008). High level of subjective well-being can also lead adolescents to the achievement of positive academic outcomes (Suldo \& Shaffer, 2008).

In contrast to the self-esteem that serves a considerable role in subjective well-being, the forgiveness variable seems to not serve a role in the subjective well-being of adolescents in this study. This differs with previous studies who found that forgiveness has a significant relationship in subjective well-being (Chan, 2013; Peterson, 2015; Plauča \& Bite, 2011). The hypothesis in this study was not proved possible because of the weakness of the Forgiveness Scale used in this study, where the scale paid too little attention to the type of conflict or wounded feelings experienced by individuals. In addition, the interval between the experience of wounded feelings and the fulfillment of the survey is not controlled hence may affect the subject's level of forgiveness. Moreover, it has yet to specify the limits of adolescent forgiveness (against whom). In some cases, an individual's level of forgiveness towards others differs in its level and intensity, for example when an adolescent is with her parents, with a close friend, with strangers, or with friends of the opposite sex.

In addition to forgiveness, this study also found that perception of family harmony does not contribute significantly as a predictor of subjective well-being of adolescents when analyzed separately. The rejection of the research hypothesis is possibly due to the orientation of adolescence that rather focuses not on families but on peers. Papalia and his colleagues (2008) explained that social development in adolescence involves peer groups more than parents (Papalia et al., 2008). Thus, in adolescence, the role of peer groups are relatively large. In adolescents' self, influence of the environment in determining behavior is admittedly quite strong, peer group is the main source of reference in terms of perceptions and attitudes related to lifestyle of adolescents in the age range of 12-18 years, hence they invest more time with their peers causing the amount of time spent with family to drastically decrease during the age of age of 10-18 years (Papalia et al., 2008).

In adolescence, peers are evidently seen to better satisfy the needs of adolescents compared to parents (Santrock, 2003). Berzonsky (1981) revealed that adolescents distinguish the role of family with friends. Sarwono (2012) elaborates that the role of parents in communication with adolescents are limited to certain matters such as education, studying, health and finance, while for sexual problems and the (relationship and feelings with) opposite sex, adolescents tend to refer more to friends. Adolescents need parents to face problems 
related to future planning, while friends are needed to solve current problems. Adolescents begin to limit dependence and expectations to parents and start spending more time with friends. Adolescents tend to do more outdoor activities, such as school activities, extracurricular and hanging-out with friends (Papalia et al., 2008). At this stage, the influence of the environment in determining behavior is very strong (Hurlock, 2002).

Discerned from today's family dynamics, particularly in Indonesia's communal society, many Indonesians have the extended family type, instead of nuclear family type. The family relationship does not only occurs between a child with his father and mother alone but also occurs with other family members such as grandparents, uncles, aunts, and other relatives. This ought to be noted for further research so the condition could be considered.

The results also showed that the coefficient of multiple determination for subjective well-being was 0.387 (seen from Adjusted R Square), meaning that $38.7 \%$ variance of subjective well-being in adolescents of this study was influenced by self-esteem, forgiveness, and the perception of family harmony, while $61.3 \%$ was influenced by other variables. Other variables that influence the subjective well-being that are not investigated in this study are, for example, religiosity (Abdel-Khalek, 2009; Abdel-Khalek, 2011; Yoon \& Lee, 2004), culture (Biswas-Diener, Diener, \& Tamir, 2004; Diener et al., 1997; Suh, Diener, Oishi, and Triandis, 1997), activities (Diener et al., 1997; Utami, 2009), social relations (Diener \& Ryan, 2009), cognitive factor (Diener et al., 1997), coping and adaptation (Diener et al., 1999), and other variables.

\subsection{Implication and Recommendation}

This research may give insight and awareness to adolescents, parents, and teachers. This research shows that self-esteem serves as a considerable role in subjective well-being, so this variable must be considered in adolescent's everyday life. Parents and teachers must be able to create a positive environment that capable of providing opportunities for adolescents to develop their positive self-esteem. The results also can be used as a reference to construct intervention module for dealing with adolescent, especially in the training and psychotherapy processes related to subjective wellbeing issues.

The results show that relationship between self-esteem, forgiveness, perception of family harmony with subjective well-being in adolescents is complex. Future researchs are needed to review other variables that influence the subjective well-being and specifications subject studied, not only limited in age but also in the family cultural background. It would also be better if the next research could explore data qualitatively, for example using depth interview, so it can enrich the data. In spite of it all, this study has provided an overview of the relationship between self-esteem, forgiveness, perception of family harmony with subjective well-being in adolescents.

\section{References}

Abdel-Khalek, A. M. (2011). Religiousity, subjective well-being, self-esteem, and anxiety among Kuwaiti muslim adolescents. Mental Health, Religion \& Culture, 14(2), 129-140. https://doi.org/10.1080/13674670903456463

Abdel-Khalik, A. M. (2009). Religiosity, subjective well-being, and depression in Saudi children and adolescents. Mental Health, Religion \& Culture, 12(8), 803-815. https://doi.org/10.1080/13674670903006755

Andayani, B., \& Koentjoro. (2004). The role of father in parenting [Peran ayah menuju coparenting]. Yogyakarta: CV. Citra Media.

Astuti, E. Y. (1999). Perceptions of family harmony, tendency of neurosis and its relation to tendency to behave delinquently in adolescents [Persepsi terhadap keharmonisan keluarga, kecenderungan neurosis dan hubungannya dengan kecenderungan berperilaku delinkuen pada remaja] (Undergraduate thesis). Faculty of Psychology Universitas Gadjah Mada, Yogyakarta, Indonesia.

Aufseeser, D., Jekielek, S., \& Brown, B. (2006). The family environment and adolescent well-being: Exposure to 
Utami, M. S., Praptomojati, A., Wulan, D. L. A., \& Fauziah, Y.

positive and negative family influences. Washington, D.C.: Child Trends.

Ayyash, H., \& Alamuddin, R. (2007). Predictors of subjective well-being among college youth in Lebanon. The Journal of Social Psychology, 147(3), 265-284. https://doi.org/10.3200/SOCP.147.3.265-284

Baron, R. A., \& Byrne, D. (2003). Social psychologyy (10 ${ }^{\text {th }}$ ed.). Boston: Allyn and Bacon.

Basson, N. (2008). The influence of psychosocial factors on the subjective well-being of adolescents (Doctoral dissertation). Retrieved from http://etd.uovs.ac.za/ETD-db/theses/available/etd-10232009-130814/unrestricted/BassonN.pdf

Baumeister, R. F., Campbell, J. D., Krueger, J. I., \& Vohs, K. D. (2003). Does high self-esteem cause better performance, interpersonal success, happiness, or healthier lifestyles? Psychological Science in the Public Interest, 4(1), 1-44. https://doi.org/10.1111/1529-1006.01431

Benet-Martínez, V., \& Karakitapoğlu-Aygün, Z. (2003). The interplay of cultural syndromes and personality in predicting life satisfaction. Journal of Cross-Cultural Psychology, 34, 38-60. https://doi.org/10.1177/0022022102239154

Berzonsky, M. D., (1981). Adolescent development. New York: MacMillan.

Biswas-Diener, R., Diener, E., \& Tamir, M. (2004). The psychology of subjective well-being. Daedalus, 133(2), 18-25. https://doi.org/10.1162/001152604323049352

Boden, J. M., Fergusson, D. M., \& Horwood, L. J. (2008). Does adolescent self-esteem predict later life outcomes? A test of the causal role of self-esteem. Development and Psychopathology, 20, 319-339. https://doi.org/10.1017/S0954579408000151

Bono,G., McCullough, M. E., \& Root, L. M. (2007). Forgiveness, feeling connectedness to others, and well-being: Two longitudinal studies. Personality and Social Psychology Bulletin, 20(10), 1-14.

Bronfenbrenner, U., \& Morris, P. (1998). The ecology of developmental process. In W. Damon \& R. Lerner (Eds.), Handbook of child psychology: Theoretical models of human development (Vol. 1, 5th ed., pp. 993-1028). Hoboken, NJ: John Wiley \& Sons.

Chan, D. W. (2013). Subjective well-being of Hong Kong Chinese teachers: The contribution of gratitude, forgiveness, and the orientations to happiness. Teaching and Teacher Education, 32, 22-30. https://doi.org/10.1016/j.tate.2012.12.005

Chuang, Y. (2005). Effects of interaction pattern on family harmony and well-being: Test of interpersonal theory, Relational-Models theory, and Confucian ethics. Asian Journal of Social Psychology, 8, 272-291. https://doi.org/10.1111/j.1467-839X.2005.00174.X

Compton, W. C. (2005). An introduction to positive psychology. Belmont: Thompson Wadsworth.

Compton, W. C., \& Hoffman, E. (2013). Positive psychology: The science of happiness and flourishing $\left(2^{\mathrm{nd}} \mathrm{ed}.\right)$. California: Wadsworth Cengage Learning.

Coopersmith, S. (1967). The antecedent of self-esteem. San Francisco, CA: WH Freedman and Company.

Deepshikha, \& Bhanot, S. (2011). Role of family environment on socio-emotional adjustment of adolescent girls in rural areas of Eastern Uttar Pradesh. Journal Psychology, 2(1), 53-56. https://doi.org/10.1080/09764224.2011.11885463

DeNeve, K. M. (1999). Happy as an extraverted clam? The role of personality for subjective well-being. Current Direction in Psychological Science, 8(5), 141-144. https://doi.org/10.1111/1467-8721.00033

Diener, E. (1984). Subjective well-being. Psychological Bulletin, 95(3), 542-575. https://doi.org/10.1037/0033-2909.95.3.542

Diener, E. (2006). Guidelines for national indicators of subjective well-being and ill-being. Journal of Happiness Studies, 7, 397-404. https://doi.org/10.1007/s10902-006-9000-y

Diener, E., \& Chan, M. Y. (2011). Happy people live longer: Subjective well-being contributes to health and longevity. Applied Psychology: Health and Well-Being, 3(1), 1-43. https://doi.org/10.1111/j.1758-0854.2010.01045.x

Diener, E., \& Ryan, K. (2009). Subjective well-being: A general overview. South Africa Journal of Psychology, 39(4), 391-406. https://doi.org/10.1177/008124630903900402

Diener, E., \& Seligman, M. E. P. (2002). Very happy people. Psychological Science, 13(1), 81-84. https://doi.org/10.1111/1467-9280.00415 
Self-esteem, forgiveness, perception of family harmony, and subjective well-being in adolescents

Diener, E., Oishi, S., \& Lucas, R. E. (2003). Personality, culture, and subjective wellbeing: Emotional and cognitive evaluation of life. Annual Review of Psychology, 54, 403-425. https://doi.org/10.1146/annurev.psych.54.101601.145056

Diener, E., Sapyta, J. J., \& Suh, E. (1998). Subjective well-being is essential to well-being. Psychological Inquiry, 9(1), 33-37. https://doi.org/10.1207/s15327965pli0901_3

Diener, E., Suh, E. M., Lucas, R. E., \& Smith, H. L. (1999). Subjective well-being: Three decades of progress. Psychological Bulletin, 125(2), 276-302. https://doi.org/10.1037/0033-2909.125.2.276

Diener, E., Suh, E., \& Oishi, S. (1997). Recent findings on subjective well-being. Indian Journal of Clinical Psychology, 24(1), 25-41.

Dogson, P. G., \& Wood, J. V. (1998). Self-esteem and the cognitive accessibility of strenghts and weaknesses after failure. Journal of Personality and social Psychology, 75(1), 178-197. https://doi.org/10.1037/0022-3514.75.1.178

Donnellan, M. B., Trzesniewski, K. H., Robins, R. W., Moffitt, T. E., \& Caspi, A. (2005). Low self-esteem is related to aggression, antisocial behavior, and delinquency. Psychological Science, 16(4), 328-335. https://doi.org/10.1111/j.0956-7976.2005.01535.x

Eid, M., \& Diener, E. (2004). Global judgements of subjective well-being: Situational variability and long-term stability. Social Indicators Research, 65, 245-277. https://doi.org/10.1023/B:SOCI.0000003801.89195.bc

Enright, R. D. (2001). Forgiveness is a choice: A step-by-step process for resolving anger and restoring hope. Washington, DC: APA.

Erol, R. Y., \& Orth, U.(2011). Self-esteem development from age 14 to 30 years: A longitudinal study. Journal of Personality and Social Psychology, 101(3), 607-619. https://doi.org/10.1037/a0024299

Eryunanti, D. (2000). Differences in self-esteem in junior high school students in Yogyakarta based on school rank, class rank, and gender [Perbedaan harga diri pada siswa SLTP Negeri di Kotamadya Yogyakarta berdasarkan peringkat sekolah, ranking kelas dan jenis kelamin]. (Unpublished undergraduate thesis). Faculty of Psychology Universitas Gadjah Mada, Yogyakarta, Indonesia.

Flanagan, K. S., Hoek, K. K. V, Ranter, J. M., \& Reich, H. A. (2012). The potential of forgiveness as a response for coping with negative peer experiences. Journal of Adolescence, 35, 1215-1223. https://doi.org/10.1016/j.adolescence.2012.04.004

Fuhrmann, B. S. (1990). Adolescence, adolescents. ( $2^{\text {nd }}$ ed.). Illinois: A Division of Scott, Foresman and Company.

Gilman, R., \& Huebner, E. S. (2006). Characteristics of adolescents who report very high life satisfaction. Journal of Youth and Adolescence, 35(3), 311-319. https://doi.org/10.1007/s10964-006-9036-7

Havlicek, J. R., Garcia, A. R., \& Smith, D. C. (2013). Mental health and substance use disorders among foster youth transitioning to adulthood: Past research and future directions. Children and Youth Services Review, 35(1), 194-203. https://doi.org/10.1016/j.childyouth.2012.10.003

Hawkins J. D., Herrenkohl T. I., Farrington D. P., Brewer, D., Catalano, R. F., Harachi, T. W., \& Cothern, L. (2000). Predictors of youth violence. Washington, DC: Department of Justice, Office of Juvenile Justice and Delinquency Prevention. 2000. Retrieved from https://www.ncjrs.gov/pdffiles1/ojjdp/179065.pdf https://doi.org/10.1037/e524202006-001

Heatherton, T. F., \& Wyland, C.L. (2003). Assessing self-esteem. In S. J. Lopez \& C. R. Synder (Eds.) Positive psychology assessment (pp. 219-233). Washington DC: American Psychological Association. https://doi.org/10.1037/10612-014

Hurlock, E. B. (2002). Development psychology: A life-span approach (Psikologi Perkembangan, Suatu pendekatan sepanjang rentang kehidupan). Translated to Indonesia by Istiwidayanti dan Soedjarwo. Jakarta: Erlangga.

Joronen, K. (2005). Adolescence's subjective well-being in their social contexts. (Doctoral dissertation. Retreived from http://www.acqol.com.au/publications/resources/thesis-joronen-k.pdf

Krause, N., \& Ellison, C. G. (2003). Forgiveness by god, forgiveness of others, and psychological well-being in late life. Journal for the Scientific Study of Religion, 42(1), 77-93. 
Utami, M. S., Praptomojati, A., Wulan, D. L. A., \& Fauziah, Y.

https://doi.org/10.1111/1468-5906.00162

Larsen, R. J., \& Eid, M. (2008). Ed Diener and the science of subjective well-being. In M. Eid \& R. J. Larsen (Eds.), The science of subjective well-being (pp. 1-13). New York: The Guiford Press.

Leary, M. R., Tambor, E. S., Terdal, S. K., \& Downs, D. L. (1995). Self esteem as an interpersonal monitor: The sociometer hypothesis. Journal of Personality and Social Psychology, 68(3), 518-530. https://doi.org/10.1037/0022-3514.68.3.518

Lee, S. K. (2003). The relationship of family interaction to Korean high school girl's career attitude maturity. International journal of Human Ecology, 14(1), 1-14.

Lucas, R. E. (2008). Personality and subjective well-being. In M. Eid \& R. J. Larsen (Eds.), The science of subjective well-being (pp. 171-194). New York: The Guiford Press.

Malone, A., Meyer, D. D., Tarlton, T., Wasielewski, L., Reuben, P., West, C., \& Mitchell, V. (2011). The relationship between forgiveness and emotional well-being. VISTAS 2011. Retrieved from http://counselingoutfitters.com/vistas/vistas11/Article_23.pdf

Marina, S., Rasni, R. A., \& Yuanita, A. (2000). The relationship between intravert-extravert type of personality and behavior of heroin abuse in adolescents [Hubungan antara tipe kepribadian intravert-ekstravert dan tingkah laku penyalahgunaan heroin pada remaja]. Jurnal Psikologi, 5(1), 1-12.

McCullough, M. E. (2000). Forgiveness as human strength: Theory, measurement, and links to well-being. Journal of Social and Clinical Psychology, 19(1), 43-55. https://doi.org/10.1521/jscp.2000.19.1.43

McCullough, M. E., Bellah, C. G., Kilpatrick, S. D., \& Johnson, J. L. (2001). Vengefulness: Relationships with forgiveness, rumination, well-being, and the big five. Personality and Social Psychology Bulletin, 27(5), 601-610. https://doi.org/10.1177/0146167201275008

McCullough, M. E., Rachal, K. C., Sandage, S. J., Worthington, E. L., Brown, S. W., \& Hight, T. L. (1998). Interpersonal forgiving in close relationships: II. Theoretical elaboration and measurement. Journal of Personality and Social Psychology, 75(6), 1586-1603. https://doi.org/10.1037/0022-3514.75.6.1586

Metzler, C. W., Biglan, A., Embry, D D., Sprague, J. R., Boles, S. M., \& Kavanagh, K. A. (2007). Improving the well-being of adolescents in Oregon. Eugene, OR: Center on Early Adolescence, Oregon Research Institute.

Miller, E. D., \& Harvey. J. H. (2001). The interface of positive psychology with psychology of loss: A brave new world. American Journal of Psychotherapy, 55(3), 313-322.

Mönks, F. J., Knoers, A. M. P., \& Haditono, S. R. (2004). Developmental psychology: Introduction in various parts [Psikologi perkembangan: Pengantar dalam berbagai bagiannya]. Yogyakarta: Gadjah Mada University Press.

Myers, D. G. (2008). Social psychology ( $9^{\text {th }}$ ed.). New York: McGraw-Hill.

Olson, D.H., DeFrain, J., \& Skogrand, L. (2014). Marriages and families: Intimacy, diversity, and strengths (8 ed.). New York: The McGraw-Hill Companies.

Papalia, D. E., Olds, S. W., \& Feldman, R. D. (2008). Human development $\left(10^{\text {th }}\right.$ ed.). New York: The McGraw-Hill Companies.

Pavot, W. \& Diener, E. (2004). The subjective evaluation of well-being in adulthood: Findings and implications. Ageing International, 29(2), 113-135. https://doi.org/10.1007/s12126-004-1013-4

Pavot, W. (2008). The assessment of subjective well-being: Successes and shortfalls. In M. Eid \& R. J. Larsen (Eds.), The science of subjective well-being (pp. 124-140). New York: The Guiford Press.

Peterson, J. (2015). Examining the relationship between forgiveness and subjective well-being as moderated by implicit religiousness and spirituality. Clinical Psychology Dissertations. Paper 3. Retrieved from http://digitalcommons.spu.edu/cpy_etd/3

Plauča, I., \& Bite, I. (2011). Relationship between forgiveness, subjective well-being and perceived relationship quality. Presented in $11^{\text {th }}$ European Conference on Psychological Assessment. Retrieved from http://www.ecpa11.lu.lv/files/Ilze\%20Plauca.pdf

Primasari, A., \& Yuniarti, K. W. (2012). What make teenagers happy? An exploratory study using indigenous psychology approach. International Journal of Research Studies in Psychology, 1(2), 53-61. https://doi.org/10.5861/ijrsp.2012.v1i2.80 
Self-esteem, forgiveness, perception of family harmony, and subjective well-being in adolescents

Proctor, C., Linley, P. A., \& Maltby, J. (2010). Very happy youths: Benefits of very high life satisfaction among adolescents. Social Indicators Research, 98, 519-532. https://doi.org/10.1007/s11205-009-9562-2

Pudjijogyanti, C. R. (1995). Self-concept in education [Konsep diri dalam pendidikan] (4 ${ }^{\text {th }}$ ed.). Jakarta: Penerbit Arcan.

Purnama, A. (2006). Adolescent happiness in terms of self esteem and the value of materialism [Kebahagiaan remaja ditinjau dari harga diri dan nilai materialism]. (Unpublished masteral thesis). Faculty of Psychology Universitas Gadjah Mada, Yogyakarta, Indonesia.

Raboteg-Šarić, Z., Brajša-Žganec, A., \& Šakić, M. (2008). Life satisfaction in adolescents: The effects of perceived family economic status, self-esteem, and quality of family and peer relationships. Primljeno, 3(4), 547-564.

Rask, K., Åstedt-Kurki, P., Paavilainen, E., Laippala, P. (2003). Adolescent subjective well-being and family dynamics. Scandinavian Journal of Caring Sciences, 17, 129-138.

Retnowati, S., \& Munawarah, M. (2009). Hardiness, self-esteem, social support and depression in adolescent disaster survivors in Yogyakarta [Hardiness, harga diri, dukungan sosial dan depresi pada remaja penyintas bencana di Yogyakarta]. Humanitas, 6(2), 105-122.

Rojas, J. R., \& Coker, T. R. (2015). The cause and consequence of mental health problems among at-risk youth. Journal of Adolescent Health, 57, 453-454. https://doi.org/10.1016/j.jadohealth.2015.08.006

Santoso, S. W. (2011). [Involvement, self-esteem, and social competence as a predictor of competition in adolescents] Keterlibatan, keberhargaan, dan kompetensi sosial sebagai prediktor kompetisi pada remaja. Jurnal Psikologi, 38(1), 52-60.

Santrock, J. W. (2003). Adolescence (Perkembangan remaja) (6 ${ }^{\text {th }}$ ed.). Translated to Indonesia by Shinto B. Adelar dan Sherly Saragih. Jakarta: Erlangga.

Sarwono, S. W. (2012). Adolescent psychology [Psikologi remaja] (Rev. ed.). Jakarta: PT Raja Grafindo Persada.

Schimmack, U., \& Diener, E. (2003). Predictive validity of explicit and implicit self-esteem for subjective well-being. Journal of Research in Personality, 37, 100-106. https://doi.org/10.1016/S0092-6566(02)00532-9

Simonton, D. K., \& Baumeister, R. F. (2005). Positive psychology at the summit. Review of General Psychology, 9(2), 99-102. https://doi.org/10.1037/1089-2680.9.2.99

Snyder, C. R., \& Lopez, S. J. (2007). Positive psychology: The scientific and practical explorations of human strengths. California: Sage Publications.

Southerland, D., Casanueva, C. E., \& Ringeisen, H. (2009). Young adult outcomes and mental health problems among transition age youth investigated for maltreatment during adolescence. Children and Youth Services Review, 31, 947-956. https://doi.org/10.1016/j.childyouth.2009.03.010

Steinberg, L. (2002). Adolescence (6th ed.). New York: Mc Graw-Hill Companies, Inc.

Subowo, E., \& Martiarini, N. (2009). The relationship between adolescent self-esteem with achievement motivation in students of SMK Yosonegoro Magetan [Hubungan antara harga diri remaja dengan motivasi berprestasi pada siswa SMK Yosonegoro Magetan]. Psikohumanika, 11(2), 20-30.

Suh, E., Diener, E., Oishi, S., \& Triandis, H. C. (1998). The shifting basis of life satisfaction judgements across cultures: Emotions versus norms. Journal of Personality and Social Psychology, 74(2), 482-493. https://doi.org/10.1037/0022-3514.74.2.482

Suldo, S. M., \& Shaffer, E. J. (2008). Looking beyond psychopathology: The dual-factor model of mental health in youth. School Psychology Review, 37(1), 52 - 68.

Thompson, L. Y., \& Snyder, C. R. (2003). Measuring forgiveness. In S. J. Lopez \& C. R. Snyder (Eds.), Positive psychological assessment: A handbook of models and measures (pp. 301-312). Washington, DC: American Psychological Association. https://doi.org/10.1037/10612-019

Thompson, L. Y., Snyder, C. R., Hoffman, L., Michael, S. T., Rasmussen, H. N., Billings, L. S., Heinze, L., Neufeld, J. E., Shorey, H. S., Roberts, J. C., \& Roberts, D. E. (2005). Dispositional forgiveness of self, others, and situations. Journal of Personality, 73(2), 313-359. https://doi.org/10.1111/j.1467-6494.2005.00311.x

Triton, P. B. (2006). SPSS 13.0 Applied: Parametric statistical research [SPSS 13.0 Terapan: Riset statistik 
Utami, M. S., Praptomojati, A., Wulan, D. L. A., \& Fauziah, Y.

parametrik]. Yogyakarta: Penerbit Andi.

Utami M. S. (2009). Involvement in student activities and subjective well-being among students [Keterlibatan dalam kegiatan dan kesejahteraan subjektif mahasiswa]. Jurnal Psikologi, 36(2), 144-163.

Utami, M. S. (2010). Subjective well-being scale[Skala kesejahteraan subjektif mahasiswa]. (Unpublished Research Report). Faculty of Psychology, Universitas Gadjah Mada, Yogyakarta, Indonesia.

Williamson, I., \& Gonzales, M. H. (2007). The subjective experience of forgiveness: positive construals of the forgiveness experience. Journal of Social and Clinical Psychology, 26(4), 407-446. https://doi.org/10.1521/jscp.2007.26.4.407

Wohl, M. J. A., DeShea, L., \& Wahkinney, R. L. (2008). Looking within: Measuring state self-forgiveness and its relationship to psychological well-being. Canadian Journal of Behavioural Science, 40(1), 1-10. https://doi.org/10.1037/0008-400x.40.1.1.1

Worthington, E. L., \& Wade, N. G. (1999). The psychology of unforgiveness and forgiveness and implications for clinical practice. Journal of Social and Clinical Psychology, 18(4), 385-418. https://doi.org/10.1521/jscp.1999.18.4.385

Wulandari, I. R. (2009). The relation of forgiveness to psychological well-being in adolescents [Hubungan pemaafan dengan kesejahteraan psikologis pada remaja] (Undergraduate thesis). Faculty of Psychology Universitas Gadjah Mada, Yogyakarta, Indonesia.

Yoon, D. P., \& Lee, E. K. O. (2004). Religiousness/spirituality and subjective well-being among rural elderly whites, African Americans, and Native Americans. Journal of Human Behavior in the Social Environment, 10(1), 191-211. https://doi.org/10.1300/J137v10n01_05 